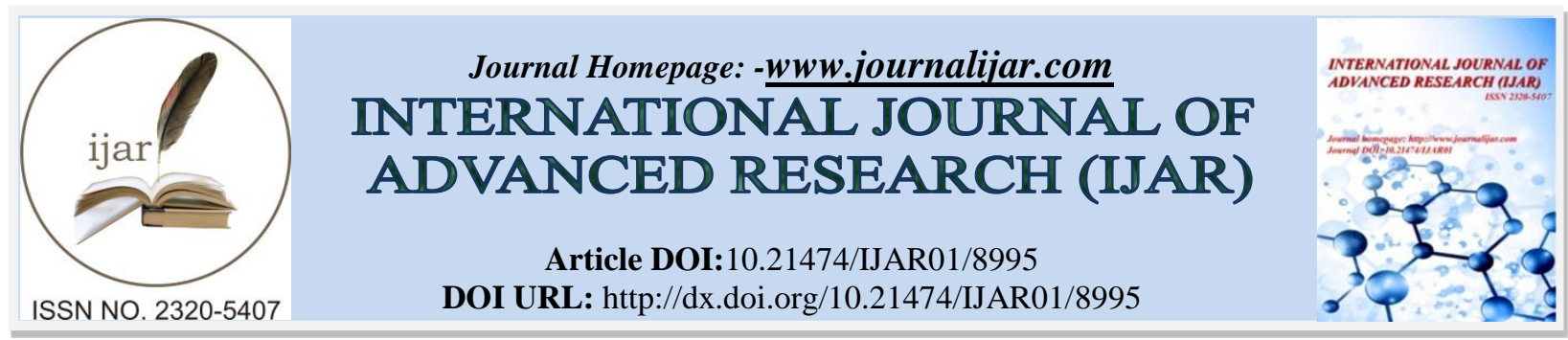

RESEARCH ARTICLE

\title{
RELIGIOUS CONVERSATION AND TRIBES IN CHHATTISGARH IN INDIA: A CASE STUDY.
}

\author{
Dr. Ravindra Nath Sharma. \\ Head, Departement. of Sociology \& Social work, Shri Sai Baba Adarsh Mahavidyalaya Ambikapur, Distt- Surguja, \\ Chhattisgarh.
}

\section{Manuscript Info}

Manuscript History

Received: 27 February 2019

Final Accepted: 29 March 2019

Published: April 2019

Key words:-

Religious Conversion, Tribes, Culture,

Customs and Tradition.

\section{Abstract}

The research work is inducted in by the tribal dominant jashpur district of Chhattisgarh. It includes 300 respondents residing in the district and has undergone religious conversion. The researcher has studied their religious rituals in sociological perspective. The researcher has tried to know the entire of people by case study of Christian missionaries, sarpanch, religious heads and also people related to these institution these interviews has been presented in chronological order.

Copy Right, IJAR, 2019,. All rights reserved.

\section{Introduction:-}

\section{Case Study -I}

Mr. "K" Caste Uraon; Religion - Christianly; Profession- Teacher; age- 48 years; mortal status- married. Mr. "K" is employed as a primary school teacher in the research area since last 18 years according to you; your great grandfather has exempted Hindu religion and accepted Christianity about 100 years ago from today. Your Christian wife and children go to church every day and celebrate all festivals of Christianity. in an answer to the question that do you still follow your old religious customs and tradition he answered that we can never leave our old customs, though there has been a change in the way we adopt them. The old heritage is largely reflected in customs we follow in birth, death, marriage, you also accepted that even though there is pressure by the chaplain to leave the Hindu customs and tradition. Though you have also accepted that the new generation is getting speedily detached from these tradition these has resulted in form of stratification. In a answer to the question that does this religions conversion has resulted in, cultural differentiation in tribal society, you said "Yes" Christian missionaries do not want them to keep themselves attached with any Hindu recognition. is there class among these two tradition so he believed that yes there are class many times. As a sum up the study, according to $\mathrm{Mr}$. $\mathrm{K}$ due to Christianity there is rapid vanishing of their religious tradition and customs. The stratification in tribal societies have caused differences in them.

\section{Case Study -II}

Smt. "rd" Caste uraon ; religion- Christianity; profession, Bank employed, age- 38 years; marital status married. Smt. "rd" is employed as employe of a nationalized bank from 12-14 years in the research area. You say that about 3 decade ago your ancestors have adopted Christianity getting influenced by church. Your life style is completely influenced by Christianity. Your marriage is however hidden from reality in Hinduism. You say that there was much pressure of missionaries on your family and its member to adopt Christianity. But you believe that, due to your marriage. You have been unaffected by it. In an answer to the question on religious rituals, you said that you have changed your religious ritual, your culture you say that you still go to temple and worship your diety. Do you face any restriction by the related people for this work you say yes, but you do not get pressurized by them. You say that

Corresponding Author:-Dr. Ravindra Nath Sharma.

Address:-Head, Departement. of Sociology \& Social work, Shri Sai Baba Adarsh Mahavidyalaya

Ambikapur, Distt- Surguja, Chhattisgarh. 
your marriage was conducted by Hindu rituals you believe that, you don't impose any restrictions on your children. As a sum according to Mrs. 'rd' inspite of religious conversion there has been to change in their religious belief.

\section{Case Study -III}

Mr. 'K' Caste- Uraon; Religion Christianity; profession- former, age- 52 years; marital status married.

Mr. "K" has been residing in the research area since last 70-80 years as a former, your answer have converted religion 3-4 generation earlier. You own 7-8 acres of land where you do agriculture. You say that your ancestors converted religious, being stressed out of poverty. After which you were given much financial support by the church. when asked that after conversion is it possible for you to perform earlier customs, you said "no" You have complete faith for church, and excepted marriage all your customs and tradition have been changed. In context of marriage you said that along with old tradition, you perform your customs in church also, in all, it can be conducted that the religious rituals of Mr. K are completely affected by conversion and he is being completely constituted with Christianity.

\section{Case Study IV}

Mr. "D" Caste- Uraon, Religion- Hindu, Profession- Ex Sarpanch, Age- 59 Years Marital- Status - marriage.

Mr. "D" is a resident of the research area since 80-90 years. You have ex sarpanch of the village. Your financial status is comparatively better. You have not undergone, religious conversion, and have4 full faith in internal (sanatan dharm). When asked about not perusing religious conversion. You answered that you cannot change your religion for sake of any temptation or greed. Your views in context of religious rituals and their effectiveness after religious conversion is that even after changing their religion, people have not been able to detach themselves completely from their religious factors. Even today there are various rituals such as birth marriage, death, social and economic rituals performed. Inspire of various endeavors. Converting religion and faith are different field according to you converted tribes even today celebrate teza, sarhul, karma, cherta, holi, faag, navratri, etc and many such festivals together with full devotion.

\section{Case Study V}

Mr. "H" Caste- Uraon, Religion- Christianity; Occupation- District project officer in a block of the district. You have an excellent experience of working in there tribal areas. You have closely seen the tribal, society and culture working with them. Thronging light on the religious conversion of tribes and conditions before conversion and the effect of conversion on social, cultural and economics ambiance, you say that religious conversion in tribal society there has developed a struggle in the infection. The attraction towards and Christianity modernity is causing a detachment and a feeling of alienation from their traditions being transferred from generation to generation there has development a problem of stratification between the tribes, who have accepted conversion of religion and those who have not accepted it. On one hand they are pressurized by the Christian missionaries to leave their hereditary tradition and on the other hand due to devotional believe they are not able to completely leave their roots. Christian missionaries want them to control them through church and keep t hem aliment with the church. Church wants them to completely adopt the Christianity. According to you there are still many such tribes who inspire of religious conversion, have been attachment to their culture it can be conducted that, even after religious conversion, there has been no effect on their religious rituals.

\section{Case Study VI}

Mr. "D" Caste- Uraon, Religion- Christianity Occupation- Nurse, Age- 28 Years ; marital status- unmarried.

Mr. "D" is employed as a staff nurse in a govt. hospital of the district, since last 4-5 years you say that your grandfather was a labor and adopted Christianity after religious conversion. According to you Christian missionaries played a major role in your education and gave major contribution You Studied nursing due to govt. scholarship your father is employed as a teacher in missionary school as a teacher since last 20-22 years. You visit church every day and participate prayer regular. Do you have any restriction in your religious practice, you answers clearly no according to you do not visit temple your family functions like birth, marriage, death etc all are précised on Christian rituals. Many tribes do not even have clear knowledge about religious practices. Conducting that Miss "D" has adopted herself completely to Christianity and its religious factors.

\section{Case Study VII}

Mr. "Y" Caste- Uraon, Religion- Hindu, Age- 21[ Marital Status- Unmarried. 
Mr. Y is a student of MSW in a college of district headquarter, and belong to oraon tribe. In a answer, when asked that why did not your ans. present religious conversation you said that they did not wanted to go anywhere else leaving their own traditions According to you, all those tribes who have practiced religious conversion are pressurized by the Christian missionaries to exempt Hindu religion completely. The tribes who have converted their religion are leaving their Hindu functions. The missionaries by mean of religious assemblies and church are installing a feeling of good and hatred for Hinduism converted tribes are feeling themselves superior than others. They are disposed to leave their culture, nursing it old. Infuriately all there is more among youth. The Youth gradually forgetting the name of traditional festivals also. Conducting it can be said that, according to Mr. "Y" religious Conversion has effected religious rituals completely.

\section{Case Study VIII}

Mr. "R" Caste- Oraon; Religion- Christianity; Occupation- college principal; age 56 years; marital status- married.

Mr. "R" is employed as a professor of sociology in a govt. college of the district you have accepted Christianity though conversion, there generation ago, your children are pursuing education; in other cities living in hostel. You have completely adopted yourself to Christian environment when asked about religious customs and tradition you said that after migration to Christianity. Though you said that your family in village still practice old traditions and they are totally untouched by religious conversation there is no restriction imposed on children also you have create a complete liberal atmosphere at your home. Conducting it can be said that according to Mr. K Christian missionaries have completely influence the tribal society in their religious rituals through religion conversation.

All the above studies point that even today the tribal society is in a state of habitation regarding the religious rituals. Though religious conversation has damaged their religious practice but, they are not able o leave their traditional believe to which they are connected, since thousands of years If anyone undergoe $4 \mathrm{~s}$, religious conversation it is harmful because there can be many religious and their belief but our cultural distinctness is same there by binding the diversities In one tag, Inspire of various end ours and clarity. Tribes have on converted their religion, but are tied with their social and cultural warp. It is a pleasant situation and an opportunity for tribal society and its youth.

\section{References:-}

1. Basu,A.R. (1985), Tribal Development Programs and Adminstration, National Book Organization, New Delhi.

2. Behura,N.K. (1995),Tribes in India: Planned development. In Singh,A.K. and Jabbi,M.K. (Eds) Tribals in India: Development, deprivation and discontent,Har Anand,New Delhi.

3. Beteille,Andre(1992), Society \& Politics in India: Essay in a comparative perspective, Oxford University Press,Delhi

4. Chaudhury,Bhagirathi(1996), Tribes and Development, Orissa Today, An Annual Survey, Sun Times, Bhuvaneshwar.

5. Chaudhuri,N.C. (1965), The Continent of circle, Bombay.

6. Heredia,RodolfeC and Srivastava Rahul (1995), Tribal identity and Minority Status (The Katkari Norms in Transition), Concept Publishing Company, New Delhi.

7. Holmberg, Allen R, (1968), Among the SorianoNomads o Long Bow, Readings in Anthropology, 2ndEdition, Vol. II.

8. Mehta (2000), Dynamics of tribal development, Anmol Publication.

9. National Conference (1990),on Problems of Scheduled Tribes, Ministry of Welfare, Tribal Development, New Delhi.

10. Nehru,Jawaharlal (1964),Speeches, September1957-April 1963, VolIII \&IV. Publication Division, Ministry of information and Broadcasting, Governmentof India,New

11. Sahay,B.N. (1968), Pragmatisation in Development: Aplication of Anthropology, Book Hive, New

12. Aphale, M.B. and Bairagi,K.V. (1984), Evaluation study of Integrated Tribal Development Project Thane-I, Jawahar,Tribal Research Bulletin, PublishedbyTRTI, Pune

13. Basu,K.K. (1956),"The History of Singhbhum, Journal of Bihar Research Society. 3.Belshaw,C.S. Development: The Contribution of Anthropology, International Social Science Journal

14. Beteille,Andre(1998), "The idea of Indigenous People”, Current Anthropology, Vol.39, No.2.5

15. Chopra,K. (1989), Forty years of resource management: The gainers and losers, Social Action.

16. Deshmukh,B.A. (2003), Tribal Development Approaches: A theoretical prospective, Tribal Research Bulletin, Published by TRTI, Pune7.Fernandes,W. (1991). 